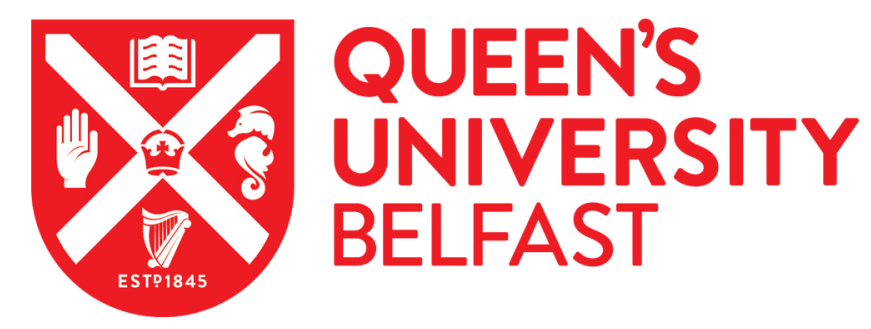

\title{
From Oz to Amazon Island: The Popular Evolution of American Matriarchalism
}

Williams, K. (2017). From Oz to Amazon Island: The Popular Evolution of American Matriarchalism. Journal of Popular Culture, 50(5), 1003-1023. https://doi.org/10.1111/jpcu.12594

\author{
Published in: \\ Journal of Popular Culture
}

Document Version:

Peer reviewed version

Queen's University Belfast - Research Portal:

Link to publication record in Queen's University Belfast Research Portal

Publisher rights

() 2017 Wiley Periodicals Inc. This work is made available online in accordance with the publisher's policies. Please refer to any applicable terms of use of the publisher.

\section{General rights}

Copyright for the publications made accessible via the Queen's University Belfast Research Portal is retained by the author(s) and / or other copyright owners and it is a condition of accessing these publications that users recognise and abide by the legal requirements associated with these rights.

Take down policy

The Research Portal is Queen's institutional repository that provides access to Queen's research output. Every effort has been made to ensure that content in the Research Portal does not infringe any person's rights, or applicable UK laws. If you discover content in the Research Portal that you believe breaches copyright or violates any law, please contact openaccess@qub.ac.uk. 
From Oz to Amazon Island: The Popular Evolution of American Matriarchalism

\section{Keira Williams}

Dorothy Gale, a farm girl from Kansas, leads a ragtag band of men through a dangerous landscape, confronts a great and terrible leader, assassinates a fearsome Wicked Witch, and goes on to form a long-term, mutually supportive sisterhood with the strange land's female leaders. A few decades later, Princess Diana, popularly known as Wonder Woman, leaves behind a race of Amazons on Paradise Island, a land of peace, prosperity, and equality, to fight for "America, the last citadel of democracy and equal rights for women" (Marston, "Introducing Wonder Woman"). Dorothy Gale, of Kansas and The Wonderful Wizard of Oz, and Wonder Woman, the Amazon of comic-book fame, are two of the most beloved female characters of twentiethcentury American culture. But these two have more in common that simply being popular figures at the center of female-driven narratives; indeed, their very foundations are linked, as both texts are premised upon the same branch of American feminist thought known as matriarchalism.

Matriarchalism can be defined broadly as the theory that human societies were originally, universally matriarchal. Its nineteenth-century proponents differed, however, on their evaluations of matriarchy as a social system. The early academic matriarchalists deemed matriarchies "savage" systems that formed based on the basic reproductive fact of matrilineage; over time, as the biological mechanics of paternity were discovered, these societies that became "civilized" through the "evolutionary advance" of patriarchy (Eller, Myth 7). Others, however, argued that this "savage" form of social organization was more accurately characterized as a democratic ideal, a lost utopia of sex equality. The latter interpretation spawned the American popular cultural version of this theory, which posits that prehistoric matriarchies represented a golden age destroyed by various historical patriarchal forces. 
An often ignored and generally subtextual theory, matriarchalism weaves through twentieth-century American popular culture, serving as a sometimes subtle, occasionally overt revision of patriarchal politics as usual. L. Frank Baum and William Moulton Marston, the respective creators of The Wizard of $\mathrm{Oz}$ and Wonder Woman, relied heavily upon matriarchalism in their fictions, embedding this controversial branch of feminist theory into mainstream popular culture through fantastical female characters. Regardless of its veracity as a theory of human prehistory, matriarchalism's long run in the original Wizard of Oz series (1900-1919) and the original Wonder Woman comics (1941-1947) is a means of charting changes in American ideas about gender, politics, and power during the first half of the twentieth century.

\section{The Matriarchalist Moment}

Heavily influenced by the work of Johann Jakob Bachofen, the original matriarchalist anthropologist who put forth a universalizing theory of prehistoric "gynecocracy" or "mother right" in the 1860s (71), anthropologist Lewis Henry Morgan made matriarchalism uniquely American through his publications based on fieldwork among the Iroquois Nations, particularly the Seneca of upstate New York. In 1877, Morgan published Ancient Society, or Researches in the Lines of Human Progress From Savagery through Barbarism to Civilization. As the subtitle indicates, social evolutionism - the theory that societies evolved at different paces along a uniform timeline from savage to civilized — was his primary premise. According to Morgan's version of evolutionism, contemporary Native Americans could offer valuable insight into the ways of the ancients (Kindle location 268). Scholars have long deconstructed the racism inherent in this kind of historical thinking, a problem that goes beyond the scope of this article, but just as significantly for Morgan, this belief in the linear evolution of all humans was thoroughly, 
inescapably gendered.

Through his fieldwork among the Seneca, Morgan came to understand that "mother right" or "gynecocracy"—primarily represented by matrilineal inheritance of property and power-was the entire principle upon which the tribes' political and economic structures were built (Kindle location 7945). Morgan firmly insisted that the "matriarchate" represented a positive, even enviable, stage of development, describing the transitions from democratic gyneocracy to patriarchal barbarism as a narrative of sociopolitical decline. Morgan's deep, if flawed, history can be seen as a warning to contemporary society that the tyranny of a patriarchal, property-based system of power would inevitably cause societal downfall as it had so often in the past. Morgan concluded with a suggestion that his readers learn from prehistory, elevating the matriarchal past to an example to be emulated by troubled Victorians (Kindle location 14308).

Morgan's suggestion was not generally heeded, but his work found a timely audience. At the time that Morgan was deploying matriarchalism as a means of exposing the darker side of contemporary society, politics, and economics, American feminism was solidifying as a movement. Organized feminism existed in the United States after the 1848, when activists organized the first ever women's rights conference at Seneca Falls, New York-a town named after the matriarchal nation that so intrigued Morgan. It is likely not an accident of history that some of the major feminists of the second half of the nineteenth century-Matilda Joslyn Gage, Elizabeth Cady Stanton, Sojourner Truth—were raised in Iroquois territory (Wagner; Ginzburg; Painter).

In the post-Civil War era, American feminist organizations coalesced around the issue of women's suffrage, and this provided a ripe context for Morgan's theory. In particular, Matilda 
Joslyn Gage, a major leader within the suffrage movement, found Ancient Society very compelling. As she read Morgan's work, Gage was already developing the corresponding theories that would make up her own magnum opus. Morgan's explication of gyneocracy provided for Gage the final piece of an emerging theory of American feminist matriarchalism that would come to resonate in U.S. popular culture.

In Women, Church, and State (1893), Gage charted the existence of matriarchal social structures and leaders throughout world history, arguing that sexist social forces had, over the course of thousands of years, worked deliberately to suppress and contain the power of women. Gage argued that women controlled prehistoric human societies, and that property, rights, and responsibilities were passed down through the mother's line. According to Gage, basic American principles of rights, including "inherent rights, natural equality of condition, and the establishment of a civilized government upon this basis," came directly from these prehistoric social systems that valued the abilities of all members, regardless of sex (37). Rather than a sexist, evolutionist model of world history in which "matriarchy" equaled "savagery," Gage offered a revised timeline in which Christianity appeared fairly late on the world scene and seized power through its "appeal to barbaric conception" that "declared woman to have been made for man" (525). One by one, she charted the evidence of former matriarchal societies across the globe throughout history, and one by one, she charted their destruction-sometimes rapid, due to violent colonization, and sometimes gradual, due to imperialism and economic incursions - by the patriarchal forces of Christian states. She concluded with the prediction that the development of equal rights in the United States would result in a wholly "regenerated world" (544-545).

Like Morgan, Gage found matriarchies both in prehistory and in her own backyard 
among the Iroquois nations. Her experience, however, was notably different; Gage visited local tribes not as an academic, but as a woman seeking answers to her own oppression. The local matriarchs were sufficiently impressed by Gage's understanding of their culture that, after several visits to the Mohawk reservation near Syracuse, Gage was adopted into the clan in 1893 and received the name of "She who holds the sky" (Wagner 34). These experiences heavily influenced her analysis of world history; as cultural, social, and political models, Gage wrote, "the world is indebted to the Iroquois" (Savion, Kindle location 333). But her careful research and her strident arguments did not gain much currency in the early 1890s for several reasons, including anti-suffragism and infighting within the suffrage movement (Brammer 227).

Her ideas, however, were not lost; this major work of matriarchalism eventually reached many Americans through the fantasy series written by her son-in-law, L. Frank Baum. In the original Wonderful Wizard of Oz series, Baum presents Dorothy, along with a host of other female characters, as part of a pantheon of matriarchs in homage to the influential ideology of Gage, his philosophical mentor.

\section{Matriarchalism Goes Mainstream}

Baum and Gage were very close; in addition to their mutual love for Maud Gage Baum, the two shared political, cultural, and religious views, and even, at the end of Gage's life, a home. In the 1890 s, after Baum had tried his hand at acting, retail, journalism, and traveling sales, Gage, who had listened to him tell his sons fantastical tales for years while failing to hold down a steady job, urged Baum to write and submit his stories. After much prompting, in 1898, at the very end of Matilda's life — she died after a devastating stroke that spring — Baum was seized with what he called his "big idea" (Schwartz 263-264). This idea was, of course, The Wizard of 
$\mathrm{Oz}$, and it was not, in fact, his alone: the gender politics of Matilda Gage are written all over the series. In the spring of 1898, mourning his mother-in-law, Baum created a fairyland that became, as it developed over fourteen books and two decades, a matriarchal utopia featuring failed patriarchs and strong female leaders.

Baum offered readers a land that thrived on diversity and female rule. Under the sham rule of the so-called Wonderful Wizard, Oz is populated with inept men. The young protagonist Dorothy rescues her male traveling companions one by one from various predicaments; the Scarecrow, the Tin Woodman, and the Lion, despite their large sizes and advanced ages compared to Dorothy, are generally messes until she comes along. The Wizard is the most obvious representation of pure patriarchy, yet the Great and Powerful Oz turns out to be all bluster, reduced to simply "The Great Humbug" in the final chapters. When Toto, Dorothy's dog, tips over a screen to reveal "a little old man, with a bald head and a wrinkled face, who seemed to be as much surprised as they were," readers witness Baum's representation of the fallacy of patriarchal rule (Baum, Wizard Kindle location 1099). All the while, throughout their dangerous journeys, young Dorothy (no older than eleven or twelve in the original book) is the brains of the operation. In each book in which Dorothy appears, she is the leader of a quest, and she always, eventually, succeeds.

There are many other powerful female characters that counteract the humbug patriarch. Using Gage's detailed research about witches in world history, Baum peopled his fairy tale with both good and wicked witches. In Baum's world, the wicked witches are threats to equality-in addition to being generally nasty, every one of them is a slaveowner. The most famous of the bad witches is the Wicked Witch of the West, whom Dorothy has to defeat in order to get back to Kansas. For this adventure, Dorothy dons a "pure white" dress - the mark of her increasing 
power, as only "witches and sorceresses wear white" in the color palette of $\mathrm{Oz}$ - and, after facing a pack of wolves, a flock of crows, a swarm of bees, a band of flying monkeys, and enslavement, she defeats the Wicked Witch with a mere bucket of water (Baum, Wizard Kindle location 943).

In Baum's world, good is more powerful than evil, and his positive representations of witchcraft conform to those offered by his mother-in-law in Women, Church, and State. The historical treatment of accused witches was of particular interest to Gage, as this charge was seen as morally, socially, and politically threatening, and it was duly punished as a crime against both church and state. Gage argued that accused witches represented the clearest threat to patriarchy because "the witch was in reality the profoundest thinker, the most advanced scientists of those ages" (Kindle location 3946). Scholars, including Gage, have long noted the gendered symbolism of water, including its history in the identification and execution of witches, its role as a purifying and baptismal agent, and its symbolism of "household drudgery" (Anderson 238). Given Gage's interest in witches, religion, and oppression within the domestic sphere, it is probable that Baum intended this multifaceted symbolism in the defeat of the Wicked Witch of the West.

On the other hand, true to Gage's belief that early matriarchies were the source of ethics, equality, and love, the good witches of $\mathrm{Oz}$ always use their power to advance Baum's utopian vision. The most famous of the magical matriarchs is Glinda, the Good Witch of the North. In her palace she keeps the Great Record Book, "on the pages of which are constantly being printed a record of every event that happens in any part of the world, at exactly the moment it happens," which gives her a kind of omniscience - the Scarecrow explains that "nothing that goes on in the Land of Oz escapes her notice" (Glinda Kindle location 22884; Marvelous Land Kindle location 2944). In later books, Glinda proves to be a potent sorceress and military strategist, commanding 
a formidable army of girls, although she prefers diplomacy to warfare (Glinda Kindle location 22959; Emerald City Kindle location 9900).

In a nod to Gage's global history of witchcraft, Baum contrasts civilization, in which there are no witches, to the barbarism of $\mathrm{Oz}$, in which witches are the most powerful beings. Dorothy, in her attempt to understand the role of witches in Oz, protests that Aunt Em told her "that the witches were all dead-years and years ago." The Good Witch of the North replies that witches are a matter of geography, because they no longer exist in "civilized countries" (Wizard Kindle location 131). Here Baum was toying with the contemporary notion of civilization. In The Road to $\mathrm{Oz}$, he explained: "...to become civilized means to dress as elaborately and prettily as possible, and to make a show of your clothes so your neighbors will envy you, and for that reason both civilized foxes and civilized humans spend most of their time dressing themselves" (Kindle location 6736). Indeed, Dunkiton, a ridiculous land even by Ozian standards, is populated by "clever donkeys" who are the "center of the world's highest civilization" (Road Kindle location 6869). Baum thus poked fun at popular Western notions of civilization and evolutionism, and in doing so, he elevated the notion of "barbaric" female rule in accordance with the theory of matriarchalism.

Female power in $\mathrm{Oz}$ is not limited to fantastical beings. If Glinda the Good Witch is the mother of $\mathrm{Oz}$, the primary matriarchy of day-to-day rulers is a cooperative one, a partnership between Dorothy and the Princess Ozma, who has a birthright claim to the throne of Oz. In the figure of Ozma, Baum presents the legitimate matriarch of the fairyland, and the people of $\mathrm{Oz}$ constantly express their approval, worshipping her almost like a goddess. Like Glinda, Ozma holds a military role as commander-in-chief of the heads of each of the four countries of Oz. Over time, Dorothy and Ozma, the two budding matriarchs, come to function as equals; like 
Ozma, Dorothy is revered in Oz. The people of Oz erect a life-sized statue of her in a public square, in honor of her crucial role in the land's history as a liberator of the Munchkins and the Winged Monkeys and as a restorer, as she enabled the retaking of the throne by the rightful matriarch by exposing the Wizard. By the sixth book, Dorothy enters the royal ranks of Oz when she becomes a Princess (Road Kindle locations 7498, 7377; Emerald City Kindle location 8273). By establishing a matriarchy, ruled over by the lawful and ethical Princess Ozma, with crucial help from her mortal companion Dorothy and Glinda the Good Witch, Baum's fairyland did more than give women power that they did not have in turn-of-the-century America. Female rule in $\mathrm{Oz}$ had far-reaching effects; in fact, it eradicated all possible social problems. Echoing some of the feminist, socialist, utopian fiction of the era, Baum explains that, in the Oz economy, the state owns the means of production, and there are no rich and no poor. Labor is similarly divided equitably, and there is no discrimination of any kind in this land in which lions and mice are treated the same, as Baum explains in The Road to $\mathrm{Oz}$ and The Emerald City of $\mathrm{Oz}$ (Road Kindle locations 7396, 7560; Emerald City Kindle locations 8154, 8147).

Although some scholars have argued that $\mathrm{Oz}$ is racially coded, as differences between beings are often expressed through color, it is not the case that difference denotes a social hierarchy; rather, Oz is thoroughly, happily diverse (Ritter 173; Parker). The Scarecrow explains, "I am convinced that the only people worthy of consideration in this world are the unusual ones" (Marvelous World Kindle location 2625). The Cowardly Lion echoes this sentiment: "Let us be glad...that we differ from one another in form and disposition" (Lost Princess Kindle location 18648). In The Magic of Oz (1919), the thirteenth book in the series, two characters debate creating a hybrid animal by combining several creatures; "the queerer, the better," they say of their potential creation (Kindle location 21766). Even Uncle Henry, the unhealthy, feeble 
patriarch from Kansas, realizes that $\mathrm{Oz}$ "is a queer country, and we may as well take people as we find them" (Emerald City Kindle location 8945).

Baum's Oz books, according to one scholar, represent a "queer utopia"_-"queer" meaning, in the context of children's literature, "odd," although not devoid of its sexual connotations - which "display[s] an antinormative sensitivity in their celebration of the unique, the eccentric, and the downright peculiar" (Pugh 218). All inhabitants of Oz have a political voice via equal access to Ozma, who listens patiently to her subjects and always responds in a fair manner. Individualism and self-reliance, as many scholars have argued, are integral to $\mathrm{Oz}$, but solidarity and collective activism are just as, if not more, salient to the plot of each book in the series (Moore 17). According to Baum's imagination and his mother-in-law's painstaking historical research, this is all due to the benevolent rule of women.

Baum's Oz, then, is a matriarchal monarchy based on the fundamental ideal of equalityan ideal that Matilda Gage said is inherent in the rule of women, but was nowhere to be found in the early-twentieth-century US, in which sexism, racism, and xenophobia reigned. Over the course of Baum's series from 1900 to 1919 the fight for suffrage - the goal to which Gage had dedicated her life - intensified as a new generation of "first wave" feminists fought for a federal amendment. In 1919, Baum was writing faithfully of his matriarchal fantasy when he succumbed to his lifelong heart condition, and the US Congress was just weeks shy of approving the Susan B. Anthony Amendment granting women the right to vote (Schwartz 297-298). Through the failed patriarchs and powerful women of The Wizard of Oz, American matriarchalism, once an esoteric academic theory, went mainstream, just as women gained this fundamental right. Although matriarchalism's primary popular vehicle in this era was a fictional fairyland, its premise of the perversions of patriarchy and the powerful potential of women's political 
participation should not be dismissed as fantastic, as it reflected major changes in American society.

Many Americans, however, are more familiar with the 1939 film version than with Baum's series of children's books, and the differences between the two texts are indicative of changes in the historical contexts of feminism in the 1910s and 1930s. In 1900, at the beginning of the series, Baum indicated that the sad land of Kansas, and by extension, the United States, was capable of reform, when Dorothy explains to her friend the Scarecrow, "No matter how dreary and gray our homes are, we people of flesh and blood would rather live there than in any other country, be it ever so beautiful." And then she states her famous mantra for the first time: "There is no place like home" (Wizard Kindle location 254). But later in the series, Dorothy, and in fact her entire family, choose to live in the utopia of Oz. Dorothy's Aunt Em, a former farmwife in Kansas turned pampered royal guest in Oz, explains: "I've been a slave all my life. I guess we won't go back to Kansas, anyway. I'd rather take my chances with the rest of you" (Emerald City Kindle location 9916).

This moment of choice is significant, as it disrupts the usual narrative arc of the genre. Authors of children's literature use the fantastical to toy with readers' expectations, but part of those expectations in this genre is a "return to ideological and cultural normativity," as when Alice wakes up from her dream of Wonderland (Pugh 219). But when Dorothy and her family choose to remain in $\mathrm{Oz}$, the utopia becomes, in a sense, real; it is not a fantasy, or dream, within the fictional story. In Baum's series, there is no return to the normalcy of the contemporary US. Rather, Oz-diverse, socialist, matriarchal Oz—becomes the new norm.

But in the 1939 film, Oz is a "bad dream," according to Auntie Em. Although the Munchkins sing to Dorothy that she will be "history" in the "hall of fame" for her heroic deeds in 
$\mathrm{Oz}$, they are a figment of her imagination, and one to which she will not return; she exclaims upon awakening in her bed in Kansas: "I'm not going to leave here ever, ever again." Lest the point be missed, Dorothy spells it out to Glinda: "If I ever go looking for my heart's desire again, I won't go any further than my own backyard" (The Wizard of Oz). This is a heartwarming message about the value of home, to be sure, but it is also a gendered lesson about where young Dorothy belongs. By the late 1930s, then — after the decline of organized feminism in the 1920s and the subsequent economic depression - the matriarchy of $\mathrm{Oz}$ had been fully tamed into a mere dream.

\section{Psychological Propaganda for the New Type of Woman}

But American matriarchalism, albeit subdued, was not dead, despite the splintering of the feminist movement after the passage of the Nineteenth Amendment (Berry). In fact, as The Wizard of $\mathrm{Oz}$ was in production, an enterprising academic was developing a matriarchal theory

of his own. In November 1937, Dr. William Moulton Marston, a Harvard-educated psychologist, made a bold prediction: within a century, the United States would begin to undergo a lengthy transformation into a "sort of Amazonian matriarchy." The New York Times detailed how this evolution might occur: "within 100 years these would be a beginning toward a matriarchy; within 500 years a definite sex battle for supremacy; and within 1,000 years the matriarchy would begin to emerge and women would take over the rule of the country, politically and economically" ("Marston Advises 3 L's for Success"). The Washington Post explained further, quoting Marston: "Women have twice the emotional development, the ability for love, than man has. And as they develop as much ability for worldly success as they already have ability for love, they will clearly come to rule business and the Nation and the world." The result would be 
"an American matriarchy — a nation of amazons in the psychological rather than the physical sense" ("Neglected Amazons to Rule Men").

Here Marston was building upon his controversial psychological theories, which he had been working on for over a decade. His research, he argued, proved that women were emotionally and behaviorally (and therefore socially, economically, and politically) superior to men. Marston believed that, based upon his psychological experiments as well as his observations of gender relations in the 1930s, women were the key to resolving interpersonal and global conflict, as they could serve as "love leaders" who would use their power "exclusively for the benefit of humanity" (Marston, Emotions 396). Marston based his predictions upon statistics indicating female gains in education, employment, and politics, and he was not totally off base. In just a few years, as the United States entered World War II and industries underwent conversion to produce war materials, the domestic labor that would fuel the war, pull the American economy out of the Great Depression, and launch a long sustained period of economic growth in US history, was, in fact, noticeably female, as the Depression-era bans on married women's work decreased during the wartime emergency (Goldin 2). Marston believed fervently in future-oriented matriarchalist evolution, and he argued that American women seemed uniquely poised for major change.

But no one was listening. Although amused reporters covered his astonishing 1937 prediction, few took him seriously. This was, to Marston's chagrin, the story of his life thus far; much like Baum, Marston struggled with, and openly critiqued, the prescribed role of the male provider. "Many classmates can testify with me that it is very hard to earn a living," Marston wrote in a Harvard Class Report in 1930. "The only thing to do is to have a wife, like mine, who will go to work and support you" (Lepore Kindle location 2604). He bounced between academic 
positions for much of the 1920s, and by the 1930s he had tried to publicize his findings in various venues: academic works, self-help books, fiction, and even consultations with the motion picture industry. But his lack of success did not diminish his faith in the potential of mass media as a platform for his psychological theories. By the late 1930s, comic books had become popular with both adult and child readers after the first superheroes, Superman and Batman, debuted in 1937 and 1938 (Daniels 11). As he grew more interested in the comics, Marston came to believe that he had found his ideal medium.

As Baum had done with The Wizard of $\mathrm{Oz}$, Marston envisioned Wonder Woman as a teaching tool through which the feminist theories that he had developed based on his psychological work as well as through his personal relationships with strong women-including his wife Elizabeth Holloway, his polyamorous lover Olive Byrne, and Byrne's aunt, the famous birth control crusader Margaret Sanger (Lepore Kindle location 118)—could reach a young audience. Indeed, Marston handed out Sanger's texts as "homework" to his assistant writers on the comic, explaining that it was all they'd need to understand his heroine (Murchison, "Personal Information"). Comic books, he argued, were America's "most popular mental vitamin," representing an innovative means of reaching youth (Marston, "Why 100,000,000 Americans Read Comics"). Wonder Woman, then, combined and embodied his career-long concerns about gender conflict, as Marston explained: "Frankly, Wonder Woman is psychological propaganda for the new type of woman who should, I believe, rule the world" (Marston, Letter to Colton Waugh). In his careful representations of his ideal for modern womanhood, Marston was, as Sheldon Mayer put it, "writing a feminist book but not for women. He was dealing with a male audience" (Daniels 33). In late 1941, DC Comics gave him a trial run, and Wonder Woman was born. 
Marston thus went to work translating his longstanding psychological and matriarchalist theories to the comic superhero format. In a letter to DC Comics editor Sheldon Mayer that accompanied his first script, Marston emphasized that they must stay true to his "universal theme," the "truth" about the "great movement now under way," which he defined simply as "the growth in the power of women." He demanded bluntly: "I want you to let that theme alone —or drop the project." In this letter, Marston detailed the connection between the backstory of his new character and the contemporary gendered context:

Bear with me while I mention the under-meaning here. Men (Greeks) were captured by predatory love-seeking females until they got sick of it and made the women captive by force. But they were afraid of them (masculine inferiority complex) and kept them heavily chained lest the women put one over as they always had before. The Goddess of Love comes along and helps women break their chains by giving them the greater force of real altruism. Whereupon men turned about face and actually helped the women get away from domestic slavery - as men are doing now. The NEW WOMEN, thus freed and strengthened by supporting themselves (on Paradise Island) developed enormous physical and mental power. But they have to use it for other people's benefit or they go back to chains, and weakness. (Marston, Letter to Sheldon Mayer)

Wonder Woman, then, was to be Marston's matriarchal Trojan Horse, his means of introducing psychological and feminist theories to a new generation via the medium, comic books, that children were consuming at an unprecedented rate.

Wonder Woman was rife with the themes that populate previous matriarchal works, including Women, Church, and State and The Wizard of Oz. Most installments, as in each Oz book, feature inept, if generally well meaning, men in need of rescue by women, usually, but not 
always, the Amazing Amazon herself. In nearly every story, Wonder Woman has to save her love interest Steve Trevor, and her dominance is clear when she physically carries him in each of her first three stories. Wonder Woman's mission is to fight for the United States, but this battle often takes the form of Wonder Woman protecting Trevor, who mirrors the kind of benevolent, clueless patriarchy represented by Dorothy's male traveling companions in Oz.

But Marston's real emphasis on matriarchalism lies in Wonder Woman's origins. She is from Paradise Island, an all-female, matriarchal society founded to help women escape male oppression, where "love and justice make women strong beyond the dreams of men" ("The Menace of Doctor Poison"). Wonder Woman possesses enormous strength and speed, in addition to other powers, but she is not the matriarch of this civilization. Hippolyte, Diana's mother and Queen of the Amazons, is by far Marston's supreme "Love Leader." Hippolyte is something of a combination of Princess Ozma and Glinda the Good Witch in L. Frank Baum's series. Like Ozma, Hippolyte is a fair-minded monarch in a peaceful land of plenty, and like Glinda, she has special powers that she employs only in emergency situations. Similar to Glinda's Great Record Book, Hippolyte has the "magic sphere," a gift from the goddess Athena, that "when tuned to any time or place in the world's history its viewplate shows everything that has happened there." The magic sphere also helps Hippolyte to locate anyone at any time in the past, present, or future. She alone has access to "the secret library of Aphrodite," which contains confidential information like the location of Valhalla, the "Hall of the Slain" of Norse mythology ("The Winds of Time"). Thus, like the suppressed but wise women that populated Gage's Women, Church, and State, Hippolyte has sole knowledge of the true, full history of civilizations. In a foreshadowing of American matriarchalism in the 1970s, which was characterized by an archaeological inquiry into the existence of the ancient "divine feminine," the only figures more powerful than 
Hippolyte are the Greek goddesses who frequently appear to provide her with guidance.

Although Marston was not a fan of history — he cautioned his readers on the "vagaries of past-dwellers" and "ancestor worship" (Try Living 175)_Wonder Woman relies heavily upon the theory of universal prehistoric matriarchies. Indeed, in one issue, "The Evolution Machine," Wonder Woman visits an ancient, matriarchal "golden age when the world was perfect" ("Evolution Goes Haywire"). Like Matilda Joslyn Gage, Marston had a keen interest in unearthing the historically suppressed power of women. The goddesses in Wonder Woman were a key part of his belief that ancient mythology represented a universal truth. He connected the worship of male gods to historical problems of gender, arguing that religion justified the murder of "harmless and innocent women" under the charge of witchcraft (Try Living 179). In one issue, Wonder Woman and friends are transported back in time to Salem, MA, in 1692, where a Puritan boy falsely accuses a girl of witchcraft. The visitors from the 1940 s are put in stocks to be hanged as witches as Wonder Woman explains, "Your superstitious beliefs which cause you to kill innocent victims in cold blood are very evil! There is no such thing as a witch or a sorcerer. Some day you will bitterly regret the grave injustices you have committed!" ("The Witches' Trials"). Echoing both Gage and Baum, Marston believed that many social and religious practices presumed to have a basis in theology were aimed at controlling the power of women and achieving the ascendance of patriarchy.

Yet Wonder Woman represented a marked departure from the matriarchalism of the previous generation, as the superheroine tended to exhibit stereotypical femininity at inopportune times, a problem which subtly and contradictorily positions gender as her weakness rather than her strength. Wonder Woman swoons when Steve Trevor calls her beautiful in "The Case of the Girl in Braces," and she occasionally professes to enjoy Trevor's "caveman" antics, such as his 
violent jealousy ("The Lawbreakers' League"). Marston's own ideas about other "natural" feminine traits often come through; on her first trip to the United States, after she dumps Trevor at the hospital, Wonder Woman is "dying" to go shopping, and Diana Prince is constantly jealous of her own alter-ego as she vies for Trevor's attention ("Wonder Woman Arrives in Man's World"). Wonder Woman's violence, while not on par with that of her superheroic male counterparts, distinguishes her from the peace-loving matriarchs of $\mathrm{Oz}$, as does her consistent and patriotic encouragement of participation in the war effort, including consumer behavior, which indicates that Marston's matriarchal vision, unlike that of L. Frank Baum, did not necessitate an economic overhaul of the US political and economic systems. If Baum subtly preached peaceful revolution, Marston offered a more tempered, if sometimes aggressive, kind of reform.

\section{From Matriarchalism to Momarchy}

Given her timing — she debuted at the end of 1941—Wonder Woman obviously tapped into the Rosie the Riveter ethos of female labor during wartime, and she thus served as a major symbol of women's power during the global emergency. "Get strong!" she exhorted female readers in 1943. "Earn your own living_ - join the WAACs or WAVEs and fight for your country!" ("Wonder Woman Versus the Saboteurs"). However, the more traditional gendered aspects of Wonder Woman - the occasional emphasis on women's allegedly innate traits like submissiveness and acquisitiveness, the advocacy of stereotypical ideas of beauty, the goal of heteronormativity, and the consistently patriotic endorsement of consumer culture-increased over time, especially after other writers stepped in when Marston developed polio and then cancer in the mid-1940s. Robert Kanigher, who wrote Wonder Woman for the two decades after 
Marston's death in 1947, effectively discarded the comic's matriarchal theme. In the new "secret origin of Wonder Woman," the Amazons founded their society not because they were escaping brutal, patriarchal, enslavement, but rather because they were wracked with grief over the defeat of their men - fathers, brothers, husbands, and sons - in warfare; the men thus did the important political work of fighting wars, while the women cried at home (Kanigher, "The Secret Origin of Wonder Woman"). Wonder Woman's corresponding personal retreat to traditional femininity, represented most starkly by her obsession with marriage to Steve Trevor, reflected the increasing gender conservatism of the early Cold War. By the late 1950s, no longer a destabilizing threat to "Man's World," Wonder Woman enjoyed all sorts of stereotypical feminine situations, from marriage proposals, to babysitting, to being carried across a stream by Steve Trevor in "S.O.S. Wonder Woman" (Kanigher, "I Married a Monster!"; "Planet of the Giants"; "S.O.S. Wonder Woman").

Like its most famous super-spokesperson, matriarchalism, once a radical critique of US patriarchy, faded by the 1950s into a diffuse emphasis on middle-class wife- and motherhood as the source of women's innate power. Although in 1945 Marston was still touting Wonder Woman as "psychological propaganda" and preparation for the coming matriarchy, his brand of matriarchalism was up against a formidable new branch of the theory: momism, or the perverted matriarchy represented by the heavy-handed, emasculating mothers of popular Cold War films like My Son John (1952), Rebel Without a Cause (1955), and The Manchurian Candidate (1962). The term, famously coined by writer Philip Wylie in Generation of Vipers (1942), his "treatise on the matriarchy," spawned a body of theory and a spate of journalistic and academic publications that became a stark manifestation of Cold War-era opposition to feminism (Plant 117). American women's destiny was to reproduce, and their natural place was in the home, but 
even as wives and mothers, these women, warned one psychiatrist, represented "the gravest menace" facing the United States (Strecker 219). In other words, women were naturally powerful, but any "momarchical" sociopolitical or matriarchal development of this fearsome power was, like communism, a threat to national security that needed to be contained (Strecker $133)$.

In the face of this overt fear of women's alleged abuse of their innate power and the corresponding concerted cultural move toward domestic containment (May 14), matriarchalism lay dormant for two decades. When the theory resurfaced in the 1960s and 1970s as part of the Women's Liberation Movement, the new matriarchalists looked to ancient history, via archaeology, and to the distant future, via science fiction, in an attempt to revive American matriarchalism's feminist roots as a radical, revisionist theory of gender, power, and society. Wonder Woman resurfaced, as well, reclaimed by feminists like Gloria Steinem; the Amazing Amazon made matriarchalism mainstream in the late 1970s via the Wonder Woman live-action television show, featuring beauty queen Lynda Carter as Marston's World War II-era heroine (Steinem; Wonder Woman). Even more recently, Wonder Woman has enjoyed a resurgence in popularity, and will receive the big-screen treatment for the first time in the summer of 2017 (Dockterman).

Because of one important relationship between a mother-in-law and her daughter's husband, matriarchalism has enjoyed a long and storied, albeit often subtextual, run in American popular culture. Baum famously and fantastically translated these academic ideas into popular culture, creating a diverse land of peace and plenty ruled by women. By World War II, however, Baum's matriarchal utopia had been tamed into the mere dream of a teenaged girl who preferred bleak Kansas over Oz. Matriarchalism made a strong initial appearance in the original Wonder 
Woman series a few years later, but the death of her creator just over five years into her run spelled doom for his original, if not entirely internally consistent, matriarchalist intent. Although the superheroine's backstory featured strong women who openly critiqued patriarchal oppression by founding their own society, by the end of the 1940s, Wonder Woman came to represent the de-radicalization and even vilification of matriarchalism that characterized the Cold War era.

Matriarchalism thus came full circle within a century of its creation; much as it had during the early decades of anthropological matriarchalism in the late Victorian period, in which ancient matriarchies were depicted as savage and barbaric, denigration of female power came in many forms - labor practices, political rhetoric, popular culture — during the mid-twentieth century as an overt means of shoring up traditional (white, capitalist) patriarchy. This campaign of condemnation was so complete that the archaeologists, anthropologists, and activists of the Women's Liberation Movement virtually had to reinvent feminist matriarchalism in the $1960 \mathrm{~s}$ and 1970s. This rediscovery paralleled the historiographical fate of Gage, who, like the women about which she wrote in Women, Church, and State, had been written out of history, reduced to a mere footnote until Women's Studies scholars rediscovered her in the 1970s (Brammer 110). Matriarchalism thus continued to undergo the cycle, begun by Morgan and Gage, of co-optation and amelioration by visionaries who saw within it the germs of American ideals of equality, democracy, and peace. As a branch of American feminist theory, then, the circuitous path of matriarchalism represents an innovative and entertaining means of tracking the circuitous routes of feminist theory over the course of the twentieth century. More importantly, the study of matriarchalist popular culture helps to unveil its role as a vital branch of social and political theory based on the radical potential of placing gender and sex at the center of understandings of power in the United States. 


\section{Works Cited}

Anderson, Celia. "The Comedians of Oz." Studies in American Humor, vol. 5, no. 4. Winter 1986-1987, pp. 229-242.

Bachofen, Johann Jakob. Myth, Religion, and Mother-Right. Translated by Ralph Manheim, Princeton University Press, 1967.

Baum, L. Frank. The Emerald City of Oz (1910), in Oz: The Complete Collection. Maplewood Books, 2013. Kindle e-book. In MLA 8th edition, format these books in Kindle omnibus edition as: Baum, L. Frank. The Emerald City of Oz. 1910. Oz: The Complete Collection, Kindle ed., Maplewood Books, 2013.

---. Glinda of Oz. 1920. Oz: The Complete Collection, Kindle ed., Maplewood Books, 2013.

---. The Lost Princess of Oz. 1917. Oz: The Complete Collection, Kindle ed., Maplewood Books, 2013.

---. The Magic of Oz. 1919. Oz: The Complete Collection, Kindle ed., Maplewood Books, 2013.

---. The Marvelous Land of Oz. 1904. Oz: The Complete Collection, Kindle ed., Maplewood Books, 2013.

---. The Road to Oz. 1909. Oz: The Complete Collection. Maplewood Books, 2013. Kindle ebook.

---. The Wonderful Wizard of Oz. 1900. Oz: The Complete Collection, Kindle ed., Maplewood Books, 2013.

Berry, Mary Frances. Why ERA Failed. Indiana University Press, 1986.

Brammer, Leila R. Excluded from Suffrage History: Matilda Joslyn Gage, Nineteenth-Century American Feminist. Praeger, 2000.

Dockterman, Eliana. "Wonder Woman Breaks Through.” Time, 19 December 2016.

Eller, Cynthia. Gentlemen and Amazons: The Myth of Matriarchal Prehistory, 1861-1900. University of California Press, 2011.

---. The Myth of Matriarchal Prehistory: Why an Invented Past Won't Give Women a Future. Beacon Press, 2001.

Flexner, Eleanor, and Ellen Fitzpatrick. Century of Struggle: The Woman's Rights Movement in the United States. Harvard University Press, 1996.

Gage, Matilda Joslyn. Women, Church and State. The Truth Seeker Company, 1893.

Gardner, Martin, and Russell B Nye. The Wizard of Oz and Who He Was. Michigan State University Press, 1957.

Ginzberg, Lori D. Elizabeth Cady Stanton: An American Life. Hill and Wang, 2009.

Goldin, Claudia. "The Role of World War II in the Rise of Women's Work." National Bureau of Economic Research, http://www.nber.org/papers/w3203. Accessed 1 February 2017.

Kanigher, Robert. "I Married a Monster!" Wonder Woman, vol. 1, no. 155, DC Comics July 1965.

---. "Planet of the Giants." Wonder Woman, vol. 1, no. 90, DC Comics, May 1957.

---. "The Secret Origin of Wonder Woman." Wonder Woman, vol. 1, no. 105, DC Comics, Apr. 1959.

---. "S.O.S. Wonder Woman." Sensation Comics, vol. 1, no. 94, DC Comics, Oct. 1949.

The Manchurian Candidate. Directed by John Frankenheimer, MGM, 1952.

"Marston Advises 3 L's for Success." New York Times. 11 Nov. 1937. 
Marston, William Moulton. "The Case of the Girl in Braces." Sensation Comics, vol. 1, no. 50, DC Comics, Feb. 1946.

---. Emotions of Normal People. New York: Harcourt, Brace, \& Company, 1928.

---. "Evolution Goes Haywire." Wonder Woman, vol. 1, no. 9, DC Comics, June 1944.

---. "Introducing Wonder Woman." All-Star Comics, vol. 1, no. 8, DC Comics, Dec. 1941.

---. “The Lawbreakers' League." Sensation Comics, vol. 1, no. 46, DC Comics, Oct. 1945.

---. Letter to Colton Waugh, 5 March 1945. In William Moulton Marston, Selected Letters, 1941-1945, Dibner Library at the Smithsonian Institution.

---. Letter to Shelden Mayer, 23 February 1943. In William Moulton Marston, Selected Letters, 1941-1945, Dibner Library at the Smithsonian Institution.

---. "The Menace of Doctor Poison." Sensation Comics, vol. 1, no. 2, DC Comics, Feb. 1942.

---. Try Living. New York: Thomas Y. Crowell Company, 1937.

---. "The Winds of Time." Wonder Woman, vol. 1, no. 17, DC Comics, May 1946.

---. “The Witches' Trials.” Sensation Comics, vol. 1, no. 73, DC Comics, Jan. 1948.

---. "Wonder Woman Arrives in Man's World." Sensation Comics, vol. 1, no. 1, DC Comics, Jan. 1942.

---. "Wonder Woman Versus the Saboteurs." Sensation Comics, vol. 1, no. 5, DC Comics, May 1942.

Morgan, Lewis Henry. Ancient Society, or Researches into the Lines of Human Progress From Savagery to Barbarism to Civilization. 1877. Kindle ed., Amazon Digital Services, 2014.

Murchison, Joye Hummel. "Joye Hummel Papers." Dibner Library, Smithsonian Institutions, Washington, DC.

My Son John. Directed by Leo McCarey, Rainbow Productions, 1952.

"Neglected Amazons to Rule Men in 1,000 Years, Says Psychologist." Washington Post, 11 Nov. 1937.

Painter, Nell Irvin. Sojourner Truth: A Life, a Symbol. W.W. Norton \& Co., 1997.

Parker, David B. "Oz: L. Frank Baum's Theosophical Utopia." 1996.

Plant, Rebecca Jo. "The Repeal of Mother Love: Momism and the Reconstruction of Motherhood in Philip Wylie's America." 2001. Johns Hopkins University, Ph.D. dissertation.

Pugh, Tison. "'There lived in the land of Oz two queerly made men': Queer Utopianism and Antisocial Eroticism in Baum's Oz Series." Marvels \& Tales: Journal of Fairy-Tale Studies, vol. 22, no. 2, 2008, pp. 217-239.

Rebel Without a Cause. Directed by Nicholas Ray. Warner Brothers, 1955.

Ritter, Gretchen. "Silver Slippers and a Golden Cap: L. Frank Baum's The Wonderful Wizard of $\mathrm{Oz}$ and Historical Memory in American Politics." Journal of American Studies, vol. 31, no. 2, August 1997, pp. 171-202.

Savion, Susan. Quoting Matilda. Kindle ed., AuthorHouse, 2014.

Schwartz, Evan L. Finding Oz: How L. Frank Baum Discovered the Great American Story. Houghton Mifflin Court, 2009.

Steinem, Gloria. "Introduction.” Wonder Woman, edited by Gloria Steinem, National Periodical Publications, 1972.

Strecker, Edward. Their Mothers' Sons: The Psychiatrist Examines an American Problem. Lippincott, 1946.

Wagner, Salley Roesch. Matilda Joslyn Gage: She Who Holds the Sky. Sky Carrier Press, 1999. The Wizard of Oz. Directed by Victor Fleming, Marvin LeRoy, George Cukor, King Vidor, and 
Norman Taurog. Warner Brothers, 1939.

Wonder Woman. Created by William Moulton Marston and Stanley Ralph Ross. Warner Bros., 1975-1979. 